$\underline{\text { Araștırma Makalesi }}$

\title{
Dikenli Kabağın In Vitro Rejenerasyonu Üzerine Çalışmalar
}

\author{
İlknur KÜLAHLIOĞLU ÇEĞIIL ${ }^{1 *}$ Sebahattin ÇÜRÜK ${ }^{1}$
}

\begin{abstract}
Özet
Araştırmada, yaprak eksplantları kullanılarak yapılan rejenerasyon çalışmalarında MS ortamında farklı $\mathrm{BA}, \mathrm{GA}_{3}$ ve NAA konsantrasyonları denenmiştir. BA'nın 1 ve $1.5 \mathrm{mg} / \mathrm{L}$ konsantrasyonları (\% 100) ile NAA'nın $1 \mathrm{mg} / \mathrm{L}$ konsantrasyonu (\% 87.50) diğer uygulamalara göre daha yüksek kallus oluşturmuştur. Ancak, oluşan kalluslar karardığı için bitki üretilememiştir. Gövde tomurcukları ve sürgün uçlarının kullanıldığı rejenerasyon çalı̧̧malarında ise farklı $\mathrm{BA}$ ve $\mathrm{GA}_{3}$ konsantrasyonları içeren MS ortamları denenmiştir. Bu eksplantlarda en yüksek sürgün oluşturma oranları, 0.5 (\% 83.75) veya 0.75 (\% 87.50) $\mathrm{mg} / \mathrm{L}$ BA bulunan MS ortamlarından elde edilmiştir. Köklendirme için $400 \mathrm{mg} / \mathrm{L}$ sefotaksim sodyum'lu NAA'sız (\% 80.00) veya 0.05 (\% 100.00) mg/L NAA içeren MS ortamlarının kullanılmasının uygun olacağı belirlenmiş̧ir.
\end{abstract}

Anahtar Kelimeler: Rejenerasyon, Chayote, In vitro

\section{Studies on In Vitro Regeneration of Chayote}

\begin{abstract}
In this study, using leaf explants, different concentration of $\mathrm{BA}, \mathrm{GA}_{3}$ and NAA in MS medium as regeneration media were examined. Media with $1 \mathrm{mg} / \mathrm{L}$ or $1.5 \mathrm{mg} / \mathrm{L} \mathrm{BA}(100 \%)$ and $1 \mathrm{mg} / \mathrm{L} \mathrm{NAA}(87.50$ $\%)$ concentrations formed more callus than other treatments. However, the shoots were not obtained since the produced callus were darkened. Different BA and GA3 concentrations was used in MS medium for in vitro regeneration from stem buds or shoot tips of chayote. The highest shoot growth medium for stem buds or shoot tips was MS supplemented with $0.5(83.75 \%) \mathrm{mg} / \mathrm{L} \mathrm{BA}$ or $0.75(87.50 \%)$, and the best rooting medium was MS containing $400 \mathrm{mg} / \mathrm{L}$ cefotaxime sodium and $0.05 \mathrm{mg} / \mathrm{L}$ NAA $(100.00 \%)$ or without NAA $(80.00 \%)$.
\end{abstract}

Keywords: Regeneration, Chayote, In vitro

ORCID ID (Yazar sirasina göre)

0000-0002-1480-3942, 0000-0003-0542-3363

Yayın Kuruluna Geliş Tarihi: 06.11.2019

Kabul Tarihi: 17.12.2019

*Hatay Mustafa Kemal Üniversitesi, Ziraat Fakültesi, Bahçe Bitkileri Bölümü, HATAY

E-mail: ilknr_ilknr@hotmail.com 


\section{Dikenli Kabağın In Vitro Rejenerasyonu Üzerine Çalışmalar}

\section{Giriș}

Halk arasında "dikenli kabak" olarak adlandırılan Sechium edule (Jacq.) Swartz, dünyanın farklı ülkelerinde ve yörelerinde; Chayote, Cho-cho, Chuchu, Huisquil, Chayota, Gayota ve Sebze Armut gibi 81 farklı kelime ile isimlendirilmektedir. Bunların arasında en çok kabul gören Chayote kelimesi, kökenini Meksika'nın eski Aztek kelimeleri "chayotli" veya "chayotl" (dikenli)'den almaktadır (Aung ve ark., 1990). Anavatanı Meksika ve Guatemala olmakla birlikte, dikenli kabağın yetiştiriciliği yapılan başlıca bölgeler Brezilya, Kosta Rika, Veracruz, Meksika ve Abhazya'dır. Dikenli kabağın kromozom sayısının 2n=2x=28 olduğu bildirilmekle (Donato ve Cequea (1994) birlikte, $2 \mathrm{n}=2 \mathrm{x}=24$ olduğunu belirten raporlar (Sobti ve Singh, 1961) da mevcuttur (CadenaIniguez ve ark., 2007).

Dikenli kabağın meyveleri dışında gövdeleri, genç yaprakları ve köklerin yumru şeklindeki kısımları da yiyecek olarak kullanılmaktadır. Bitkinin yenen kısımlarının lif, protein ve vitamin içeriği diğer sebzelere oranla düşüktür. Meyve ve özellikle tohum, pek çok önemli amino asit (aspartik asit, glutamik asit, alanin, arjinin, sistein, fenilalanin, glisin, histidin, izolösin, lösin, methionin, prolin, serin, tirosin, treonin ve valin) yönünden zengindir (Saade, 1996). Dikenli kabak herhangi bir doymuş yağ içermemekle birlikte, antioksidan özelliğine sahiptir (Ordonez ve ark., 2006). Düşük kalorili olması nedeniyle kolesterol ve kilo kontrolü için diyetisyenler tarafından önerilmektedir. Kordiyovasküler değişimi sağlayan yaprakları, hipertansiyon için bitkisel ilaç olarak kullanılabilmektedir. Meyve ve köklerinin diüretik olduğu kabul edilmekte ve tohumlarının bağırsaklarla ilgili problemlere iyi geldiği belirtilmektedir (Robinson ve DockerWalters, 1997). Dikenli kabak, iri sulu kökleri bir kaç y1lda gelişebilen çok yıllık bir bitkidir. Subtropik iklim bölgelerinde sürgünleri sonbaharda donarak ölür. Fakat kış ayları sert geçmezse, köklerin üst kısmındaki adventif gözlerden ilkbaharda sürgünlerin oluşmasıyla büyüme yeniden başlar (Aung ve ark., 1990; Robinson ve Decker-Walters, 1997).

Dikenli kabak meyvelerinde; irilik, şekil, renk ve dikenlilik bakımından önemli derecede genetik farkl1liklar mevcuttur (Newstrom, 1991; Rubatzky ve Yamaguchi, 1997). Meyve tek tohumlu, etli ve sürgün üzerindeyken bile sürebilir (viviparous). Tohumundan gelişen sürgün, perikarptan beslenir (Aung ve ark., 1990; Robinson ve Decker-Walters, 1997). Kısa gün bitkisi olan dikenli kabağın meyveleri kullanılarak çoğaltılması ile ilgili olarak yapılan çalışmalar incelediğinde, çoğaltma katsayısının düşük olduğu görülmektedir. Bu bitkinin doku kültürü ile çoğaltılması konusunda ise birkaç çalışma mevcuttur. Wang ve ark. (1997), sürgün ucu segmentlerinin $1 \mathrm{mg} / \mathrm{L}$ IAA içeren MS (Murashige ve Skoog, 1962) ortamında \% 81.30 oranında köklendiğini ve tomurcuk taşıyan gövde çeliklerinin $0.3 \mathrm{mg} / \mathrm{L}$ IAA içeren $1 / 2 \mathrm{MS}$ ortamında $\% \quad 83.30$ oranında sürgün oluşturduğunu bildirmişlerdir. Transfer edilen sürgünlerin $\%$ 75.00'i bitkiye dönüşmektedir. Abdelnour ve Engelmann (2002a)'ın dikenli kabak bitkisinde yaptığ 1 çalışmada dondurularak muhafaza (kriyoprezervasyon) edilen embriyoların $0.5 \mathrm{mg} / \mathrm{L}$ BA içeren ortamda, kültüre alınması sonucu \% 10 ila 30 arasında bir gelişmenin olduğunu ve bunların \% 17 ila 38'nin hayatta kaldığını ifade etmișlerdir. Yapılan bir çalışmada dikenli kabağın mikro çoğaltımı için büyüme düzenleyicileri gereksinimlerinin çok düşük konsantrasyonda olduğu $(0.1 \mathrm{mg} / \mathrm{L}$ BA) veya bitki büyüme düzenleyicilerinin bulunmadığı ortamlarda gerçekleştiği bildirilmiştir (Sommaribas ve ark., 1997; Abdelnour ve ark., 2002b; CadenaIniguez ve ark., 2007). Sweetly ve ark. (2018), dikenli kabağın boğum eksplantlarını kullandıkları çalışmada, en yüksek sürgün sayısını (4.89 adet/boğum) $0.2 \mu \mathrm{M}$ IAA ve 0.2 $\mu \mathrm{M}$ BAP içeren MS ortamından elde ettiklerini belirtmişlerdir. Sonuç olarak, çoğaltma materyalinin pahalı olması ve yapılan in vitro çalışmalarda başarı oranının düşük olması nedeniyle, in vitro çoğaltılmasının geliştirilmesi gerekmektedir.

\section{Materyal ve Yöntem}

Doku kültüründe çoğaltma materyali olarak kullanılan dikenli kabak sürgün ve yaprakları, Belen'deki bir ev bahçesinden ve Serinyol pazarından alınan meyvelerin 5 L'lik torf:perlit (2:1) karışımı ile doldurulmuş saksılara dikilmesiyle serada elde edilen bitkilerden 


\section{Dikenli Kabağın In Vitro Rejenerasyonu Üzerine Çalışmalar}

temin edilmiștir. Doku kültürü çalıșmalarında, yukarıda belirtildiği gibi üretilen bitkilerden alınan çeliklerin yaprak koltuğunda bulunan tomurcuklar ve sürgün uçları ile gerçek yaprakları veya in vitro bitkilerin büyütme odasında yetiştirilmesi ile üretilen bitkilerin gerçek yaprakları eksplant kaynağı olarak kullanılmıştır.

Yaprak rejenerasyonu çalışmalarında dezenfeksiyon yöntemleri

Yaprak eksplantları kullanılarak yapilan rejenerasyon çalışmalarında, $100 \mathrm{ml}$ 'sinde 2 damla Tween 20 bulunan \% 0.5 veya \% 0.6 ' l $1 \mathrm{k}$ sodyum hipoklorit çözeltisinde $15 \mathrm{dk}$ manyetik karıştırıcıda çalkalandıktan sonra $3 \mathrm{kez}$ steril saf sudan geçirilmiştir. Eksplantların alanı yaklaşık $0.5 \mathrm{~cm}^{2}$ olacak şekilde ayarlanarak MS ortamı içeren Petri kaplarına $(9 \times 1.5 \mathrm{~cm})$ aktarılmıştır. Söz konusu eksplantlar $25 \pm 1{ }^{\circ} \mathrm{C}$ sicaklık, 40-50 $\mu \mathrm{mol} / \mathrm{m}^{2} \mathrm{sn} 1$ şı $\mathrm{k}$ yoğunluğunda (16 saat 1 şık, 8 saat karanlık) kültüre alınmıştır. Endojenik kontaminasyonların görülmesi halinde sefotaksim sodyum (Sefotak 1gIM/IV) kullanılmıştır.

Sürgün ucu ve tomurcuk rejenerasyonu çalışmalarında dezenfeksiyon yöntemleri

Dikenli kabağın in vitro çoğaltımını geliştirmek için uygun bir dezenfeksiyon protokolünün belirlenmesi amaciyla, bitkilerden alınan sürgün ucu veya tomurcuk bulunduran 2-3 gözlü çelikler kullanılmıştır. Çelikler, 100 ml'sinde 2 damla Tween 20 bulunan \% 0.5'lik sodyum hipoklorit çözeltisinde 10 veya $15 \mathrm{dk}$, veya \% 0.6 'lık sodyum hipoklorit çözeltisinde $15 \mathrm{dk}$ manyetik karıştırıcıda çalkalandıktan sonra $3 \mathrm{kez}$ steril saf sudan geçirilmiştir. Dezenfeksiyonunda etil alkol kullanılması gerektiğinde ise çelikler \% 70'lik etil alkol çözeltisinde 5 veya 15 sn tutulmuştur. Ardından $3 \mathrm{kez}$ steril saf sudan geçirilerek $100 \mathrm{ml}$ 'sinde 2 damla Tween 20 bulunan \% 0.6 veya \% 0.75 'lik sodyum hipoklorit çözeltisinde $15 \mathrm{dk}$ çalkalandıktan sonra $3 \mathrm{kez}$ steril saf sudan geçirilmiştir. Söz konusu eksplantlar içerisinde MS ortamı bulunan cam tüplere $(150 \times 25 \mathrm{~mm})$ aktarılarak yukarıda belirtilen bitki büyütme odası koşullarında kültüre alınmıştır. Endojenik kontaminasyonların görülmesi durumunda 400 $\mathrm{mg} / \mathrm{L}$ sefotaksim sodyum kullanılmıştır.
Yaprak rejenerasyonu çalışmalarında kullanılan ortamlar

Gerçek yaprakların rejenerasyonunda $30 \mathrm{~g} / \mathrm{L}$ sakkaroz (Duchefa S0809.1000) ve aksi belirtilmediği takdirde $8 \mathrm{~g} / \mathrm{L}$ agar (Duchefa P1001.1000) içeren MS ortamında 1) BA'nın 0, $0.1,0.3,0.5,0.75,1 \mathrm{mg} / \mathrm{L}$ ve Sefotaksim sodyumun $0,400 \mathrm{mg} / \mathrm{L}$ kombinasyonlar1, 2) $0.1,0.3,0.5 \mathrm{mg} / \mathrm{L}$ BA ve $0,0.05,0.1 \mathrm{mg} / \mathrm{L} \mathrm{GA}_{3}$ kombinasyonlar1 ile 3) BA'nın $0,0.5,1,1.5$ $\mathrm{mg} / \mathrm{L}$ ile NAA'nı $0,0.5,1,1.5 \mathrm{mg} / \mathrm{L}$ kombinasyonları denenmiştir.

Sürgün ucu ve tomurcuk rejenerasyonu çalışmalarında kullanılan ortamlar

Rejenerasyon çalışmalarında, MS ortamı temel besin ortamı olarak kullanılmıştır. Bitkilerin yaprak koltuğunda bulunan tomurcuklar ve sürgün uçlarının rejenerasyonunda 1) $0,0.1$, $0.3,0.5 \mathrm{mg} / \mathrm{L}$ BA konsantrasyonlar1, 2) BA'nın $0,0.5,0.75,1 \mathrm{mg} / \mathrm{L}$ ve $\mathrm{GA}_{3}{ }^{\prime}$ ün $0,0.5 \mathrm{mg} / \mathrm{L}$ kombinasyonları, 3) BA'nın $0,0.5,0.75,1$ $\mathrm{mg} / \mathrm{L}$ ve sefotaksim sodyumun $0,400 \mathrm{mg} / \mathrm{L}$ kombinasyonları araştırılmıştır. Sürgün oluşturma ortamında en iyi sonuç veren 0.5 ve $0.75 \mathrm{mg} / \mathrm{L}$ BA'nın 0 veya $0.5 \mathrm{mg} / \mathrm{L} \mathrm{GA}_{3}$ ile kombinasyonlarının sürgün oluşturma üzerine etkisini belirlemek için $400 \mathrm{mg} / \mathrm{L}$ sefotaksim sodyum içeren MS ortamı kullanılarak bir deneme daha kurulmuştur. Tomurcuk ve sürgün uçlarının rejenerasyonu sonucu oluşan sürgünler, en az 2-3 cm olduğunda köklendirme ortamına (Bitki büyüme düzenleyicisi içermeyen $\mathrm{MS}$ ) alınmıştır. $\mathrm{Bu}$ ortamda köklenme yüzdesi düşük olduğundan; 1) 0, 0.1, $0.2 \mathrm{mg} / \mathrm{L}$ NAA, 2) $0,0.5,1 \mathrm{mg} / \mathrm{L} \mathrm{NAA}, 3) 0$, $0.01,0.05 \mathrm{mg} / \mathrm{L}$ NAA ve NAA's1z $400 \mathrm{mg} / \mathrm{L}$ sefotaksim sodyum, 4) 0, 0.03, 0.05, $0.07 \mathrm{mg} / \mathrm{L}$ NAA içeren MS ortamlarının denendiği 4 farklı deneme kurulmuştur.

\section{Sürgün ucu ve tomurcuk rejenerasyonuyla üretilen bitkilerin aklimatizasyonu, ploidi düzeyinin belirlenmesi ve serada yetiştirilmesi}

Alınan tomurcukların in vitro kültürü sonucu rejenere olan bitkilerin dış ortama alıştırılması için 1 hafta süreyle kültür kabının kapakları kademeli olarak açılmıştır. $\mathrm{Bu}$ şekilde dış koşullara kısmen adapte edilen bitkiler, önce içinde torf:perlit karışımı $12: 1)$ bulunan viyolde veya 0.5 L'lik saksıda fide haline getirilmiştir. 


\section{Dikenli Kabağın In Vitro Rejenerasyonu Üzerine Çalışmalar}

Bu bitkilerin ploidi düzeyi Partec firmasının PI kiti ile Partec protokolü kullanılarak, Flow Sitometri ile belirlenmiştir (Tuna, 2014). Dış koşullara alıştırılan bitkiler, 5 L'lik saksılara aktarılarak serada büyütülmüştür. Söz konusu bitkiler burada belli bir büyüklüğe ulaştığında, cam serada bulunan ve yukarıda belirtildiği gibi hazırlanan torf:perlit karışımı ile doldurulan 25 L'lik saksilara 30 Kasim 2017 tarihinde dikilerek, $\quad 1.90 \quad$ x $1.25 \quad \mathrm{~m}$ aralıklarla yerleştirilmiştir. Bitkilerin sulanması, saksılardaki toprak gözlenerek ihtiyaç halinde damla sulama sistemi ile yapılmıștır. Bitkilere, 4 farklı tarihte suda çözülerek toplam 21:7:28 $\mathrm{kg} / \mathrm{da} \mathrm{N}: \mathrm{P}_{2} \mathrm{O}_{5}: \mathrm{K}_{2} \mathrm{O}$ verilmiştir.

\section{Yapılan ölçümler ve izlenen parametreler}

Dezenfeksiyon ve rejenerasyon denemeleri kurulduktan 1-2 hafta içinde kontamine olan eksplant oranı (\%), 3-4 hafta sonra canlı kalan ve süren eksplant oranı (\%) belirlenmiştir. Daha sonra kardeşlendirme ortamında eksplant başına oluşan kardeş sayısı (adet) tespit edilmiştir. Köksüz sürgünler, köklendirme ortamına alındıktan 1 ay sonra kök oluşturan bitki oranı (\%), her bitkide kök uzunluğu $(\mathrm{cm})$ ve kök sayıları (adet) belirlenmiștir. Saksılara yapılan dikimden 3 hafta sonra saksıda yaşayan bitki oranı (\%) tespit edilmiştir. Her tekerrürde rejenere olan bitkilerin 2-3'ünde ploidi düzeyi Flow Sitometri ile belirlenmiştir. In vitro rejenerasyon sonunda üretilen ve serada yukarıda belirtildiği şekilde yetiştirilen bitkiler, bitki morfolojisi, meyve oluşumu ve ploidi seviyesi dikkate alınarak somaklonal varyasyon açısından incelenmiştir.

\section{Verilerin değerlendirilmesi}

Denemeler faktöriyel düzende tesadüf parselleri deneme desenine göre kurulmuş, denemelerden elde edilen verilere varyans analizi uygulanmıştır. In vitro çalışmalarda, sürgün ucu ve tomurcuk rejenerasyonu ile yaprak eksplantı kullanılarak yapılan rejenerasyon çalışmaları 4 tekerrürden oluşmuştur ve her tekerrürde 5-7 eksplant bulundurulmuştur. Sürgün ucu ve tomurcuk rejenerasyonu sonucu oluşan köksüz bitkilerin köklendirme denemeleri 3 tekerrürlü, her tekerrürde 5-6 bitki olacak şekilde kurulmuştur. Elde edilen \% verilere açı transformasyonu uygulanmıştır ve eksplant başına düşen bitki gözlemlerinde elde edilen rakamlar 10'dan küçük olduğundan rakamlara 0.5 eklenerek karekök transformasyonu uygulanmıştır. Bu değerlerin varyans analizinde $\%$ 'te önemli çıkan parametrelerin ortalamaları Tukey (HSD) testine göre karşılaştırılmıştır.

\section{Bulgular ve Tartışma \\ Yaprak eksplantı kullanılan rejenerasyon çalışmaları}

Araştırmanın bu bölümünde, gerçek yapraklar kullanılarak kurulan 1. denemede, \% 0.50 sodyum hipoklorit konsantrasyonunun serada yetiştirilen bitki yapraklarına $15 \mathrm{dk}$ uygulanmasının dezenfeksiyonda etkinliğ $i$, farkl1 sefotaksim sodyum ve BA konsantrasyonlarının rejenerasyon üzerine olan etkisi araştırılmıştır. $\mathrm{Bu}$ dezenfeksiyon uygulamas1 ve ortama $400 \mathrm{mg} / \mathrm{L}$ sefotaksim sodyum eklenmesi sonucu ortalama \% 10.07 oranında kontaminasyon gerçekleşmiştir (Çizelge 1). Kallus oluşturan eksplant oranı bakımından, denenen faktörlerin ikili interaksiyonları önemli bulunmuştur. En yüksek kallus oluşturan eksplant oranı (\% 79.17), sefotaksim sodyum içeren ortamda 0.5 $\mathrm{mg} / \mathrm{L}$ BA konsantrasyonu uygulanmasi sonucu oluşmuştur. Sefotaksim sodyumun etkisi değerlendirildiğinde incelenen gözlemlerden kontamine olan eksplant oranına etkisi istatiksel olarak önemli bulunmuştur. Sefotaksim sodyumun uygulanmadiğ 1 ortamda kontaminasyon oranının \% 5.56'dan \% 14.58'e yükseldiği görülmektedir. Böylece denemede sefotaksim sodyumun kontaminasyon oranını azalttığ 1 değerlendirilerek olumlu etki yaratmasının yanında, yapraklarda kararma gibi olumsuz etkisinin olduğu da gözlenmiştir. Özellikle sefotaksim sodyum içeren ortamlarda söz konusu kararmanın daha fazla olduğu değerlendirilmiştir (Şekil 1). Dolayısıyla bu denemdeki hiçbir uygulamada sürgün meydana gelmemiştir.

Gerçek yaprakların kullanılmasıyla kurulan 2. rejenerasyon denemesinde yaprak eksplantları, $\% 0.60$ sodyum hipoklorit konsantrasyonunda $15 \mathrm{dk}$ süreyle dezenfekte edilmiştir. $\mathrm{Bu}$ denemede sodyum hipoklorit $\begin{array}{lllll}\text { konsantrasyonunun } & \% & 0.5 \text { 'ten } & \% & 0.6 \\ \text { 'ya }\end{array}$ yükseltilmesi sonucu oluşan kontaminasyon oranı (\% 0.40) (Çizelge 2), 1. denemeye (\% 10.07) (Çizelge 1) göre çok azalmıştır. Ayrıca, 


\section{Dikenli Kabağın In Vitro Rejenerasyonu Üzerine Çalışmalar}

Cruz-Martínez ve ark. (2017) dikenli kabakta bildirdiği gibi yapraklarda çizikler oluşturmak suretiyle rejenerasyon elde edilmeye çalışılmıştır. $\mathrm{Bu}$ denemeden elde edilen ortalama değerler Çizelge 2'de sunulmuştur. Denenen faktörlerin, incelenen özellikler üzerine etkisi istatistiksel olarak önemli bulunmamıştır. Bununla birlikte, $0.5 \mathrm{mg} / \mathrm{L}$ BA ve $0.05 \mathrm{mg} / \mathrm{L} \mathrm{GA}_{3}$ içeren sürgün oluşturma ortamından gelen bitki yaprak eksplantlarının kallus oluşturma oranının (\% 21.43) diğer uygulamalara kıyasla daha yüksek olduğu belirlenmiştir. $\mathrm{Bu}$ denemedeki uygulamalarda sadece beyaz kallus oluşumu gerçekleșmiş olup, kallusların kararmasına (Şekil 1) bağlı olarak sürgün elde edilememiştir. Ancak, CruzMartínez ve ark. (2013) yaptığ bir çalışmada, dikenli kabak embriyolarının çimlendirilmesi sonucu oluşan in vitro bitkilerin gerçek yapraklarının $\mathrm{MS}+0.1 \mathrm{mg} / \mathrm{L} \mathrm{BA}+0.5 \mathrm{mg} / \mathrm{L}$ $\mathrm{GA}_{3}$ veya $\mathrm{MS}+0.1 \mathrm{mg} / \mathrm{L} \mathrm{BA}+0.1 \mathrm{mg} / \mathrm{L} \mathrm{GA}_{3}$ ortamlarında kültüre alınması sonucu bitki elde ettiklerini bildirmişlerdir. Yine Cruz-Martínez ve ark. (2017) yapmış oldukları benzer çalışma sonunda yaprak eksplantlarında çizikler oluşturarak MS ortamında $0.1 \mathrm{mg} / \mathrm{L}$ BA ve 0.05 $\mathrm{mg} / \mathrm{L} \mathrm{GA}_{3}$ kombinasyonundan organogenesis ile bitki elde etmişlerdir. Fakat çalışmamızda yapılan gözlemler sonucunda, yaprakların yapılan çiziklerden zarar görmüş olduğu belirlenmiştir. Çiziklerin derin ve yoğun olması nedeniyle, daha önce olumlu sonuç alınmış olmakla birlikte dezenfeksiyon ișleminde kullanilan sodyum hipoklorit konsantrasyonu ve süresine $(\% 0.6,15 \mathrm{dk})$ bağl1 olarak bu zararın ortaya çıkmış olabileceği değerlendirilmiştir.

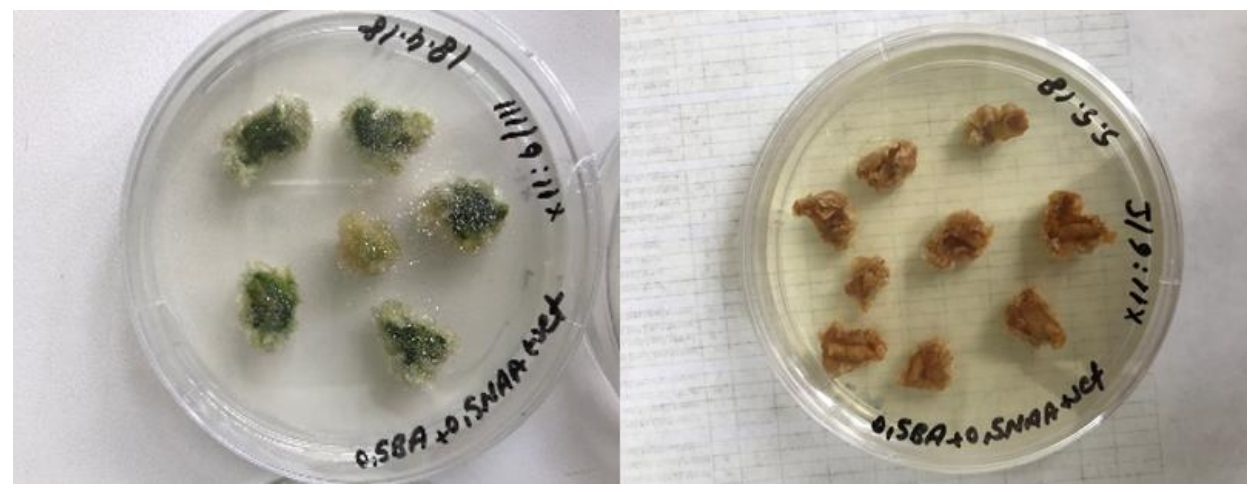

Şekil 1. Dikenli kabakta yaprak rejenerasyonu sonucu oluşan beyaz kallus (solda) ve bu kallusların daha sonra kararmasıyla oluşan eksplant görüntüsü (sağda) 
Çizelge 1. Dikenli kabak meyvelerinden gelen serada yetiştirilen sürgünlerin gerçek yapraklarına uygulanan farklı BA ve sefotaksim sodyum uygulaması sonucu elde edilen ortalama değerler

\begin{tabular}{|c|c|c|c|c|}
\hline $\begin{array}{c}\text { BA } \\
(\mathrm{mg} / \mathrm{L})\end{array}$ & $\begin{array}{l}\text { Sefotaksim sodyum } \\
\text { (mg/L) }\end{array}$ & $\begin{array}{c}\text { Kontamine } \\
\text { olan eksplant } \\
\text { oran1 }(\%)\end{array}$ & $\begin{array}{c}\text { Canlı kalan } \\
\text { eksplant oran1 } \\
(\%)\end{array}$ & $\begin{array}{l}\text { Kallus oluşturan } \\
\text { eksplant oran1 (\%) }\end{array}$ \\
\hline 0 & 400 & 16.67 & 83.33 & $0.00^{\mathrm{c}}$ \\
\hline 0.1 & 400 & 16.67 & 83.33 & $0.00^{\mathrm{c}}$ \\
\hline 0.3 & 400 & 0.00 & 100.00 & $50.00^{\mathrm{abc}}$ \\
\hline 0.5 & 400 & 0.00 & 100.00 & $79.17^{\mathrm{a}}$ \\
\hline 0.75 & 400 & 0.00 & 100.00 & $58.33^{\mathrm{abc}}$ \\
\hline 1 & 400 & 0.00 & 100.00 & $16.67^{\mathrm{abc}}$ \\
\hline 0 & 0 & 4.17 & 95.83 & $0.00^{\mathrm{c}}$ \\
\hline 0.1 & 0 & 8.33 & 91.67 & $25.00^{\mathrm{abc}}$ \\
\hline 0.3 & 0 & 0.00 & 100.00 & $41.67^{\mathrm{abc}}$ \\
\hline 0.5 & 0 & 8.33 & 91.67 & $6.25^{\mathrm{bc}}$ \\
\hline 0.75 & 0 & 62.50 & 37.5 & $31.25^{\mathrm{abc}}$ \\
\hline 1 & 0 & 4.17 & 95.83 & $75.00^{\mathrm{ab}}$ \\
\hline \multicolumn{2}{|c|}{ Tukey HSD (\% 5) } & Ö.D & Ö.D & 11.04 \\
\hline \multicolumn{5}{|c|}{$\mathrm{BA}(\mathrm{mg} / \mathrm{L})$} \\
\hline \multicolumn{2}{|r|}{0} & $10.42^{\mathrm{ab}}$ & 89.58 & $0.00^{\mathrm{b}}$ \\
\hline \multicolumn{2}{|r|}{0.1} & $12.50^{\mathrm{ab}}$ & 87.50 & $12.50^{\mathrm{ab}}$ \\
\hline \multicolumn{2}{|r|}{0.3} & $0.00^{\mathrm{b}}$ & 100.00 & $45.83^{\mathrm{a}}$ \\
\hline \multicolumn{2}{|r|}{0.5} & $4.17^{\mathrm{b}}$ & 95.83 & $42.71^{\mathrm{a}}$ \\
\hline \multicolumn{2}{|r|}{0.75} & $31.25^{\mathrm{a}}$ & 68.75 & $44.79^{\mathrm{a}}$ \\
\hline \multicolumn{2}{|c|}{1} & $2.08^{\mathrm{b}}$ & 97.92 & $45.83^{\mathrm{a}}$ \\
\hline \multicolumn{2}{|c|}{ Tukey HSD (\% 5) } & 21.05 & Ö.D & 33.21 \\
\hline \multicolumn{5}{|c|}{ Sefotaksim sodyum $(\mathrm{mg} / \mathrm{L})$} \\
\hline \multicolumn{2}{|c|}{0} & $14.58^{\mathrm{a}}$ & 85.42 & 29.86 \\
\hline \multicolumn{2}{|c|}{400} & $5.56^{\mathrm{b}}$ & 94.44 & 34.03 \\
\hline \multicolumn{2}{|c|}{ Tukey HSD (\% 5) } & 8.19 & Ö.D & Ö.D \\
\hline
\end{tabular}

Varyans analizi önemli bulunan uygulamaların aynı sütundaki ortalamaları arasındaki farklılıklar, Tukey testiyle $\mathrm{P} \leq 0.05$ 'e göre belirlenmiştir. ÖD: Önemli Değil 
Çizelge 2. In vitro ortamdan gelen ve bitki büyütme odasında yetiştirilen bitki sürgünlerinin gerçek yapraklarına uygulanan farklı BA ve $\mathrm{GA}_{3}$ konsantrasyonları sonucu elde edilen ortalama değerler

\begin{tabular}{|c|c|c|c|c|}
\hline $\mathrm{BA}(\mathrm{mg} / \mathrm{L})$ & $\mathrm{GA}_{3}(\mathrm{mg} / \mathrm{L})$ & $\begin{array}{l}\text { Kontamine olan } \\
\text { eksplant oran1 }(\%)\end{array}$ & $\begin{array}{c}\text { Canlı kalan } \\
\text { eksplant } \\
\text { oranı (\%) }\end{array}$ & $\begin{array}{c}\text { Kallus } \\
\text { oluşturan } \\
\text { eksplant oranı } \\
(\%)\end{array}$ \\
\hline 0.1 & 0 & 0.00 & 100.00 & 4.17 \\
\hline 0.1 & 0.05 & 3.57 & 96.43 & 0.00 \\
\hline 0.1 & 0.1 & 0.00 & 100.00 & 0.00 \\
\hline 0.3 & 0 & 0.00 & 100.00 & 7.14 \\
\hline 0.3 & 0.05 & 0.00 & 100.00 & 0.00 \\
\hline 0.3 & 0.1 & 0.00 & 100.00 & 0.00 \\
\hline 0.5 & 0 & 0.00 & 100.00 & 4.17 \\
\hline 0.5 & 0.05 & 0.00 & 100.00 & 21.43 \\
\hline 0.5 & 0.1 & 0.00 & 100.00 & 3.57 \\
\hline \multicolumn{2}{|c|}{ Tukey HSD (\% 5) } & Ö.D & Ö.D & Ö.D \\
\hline \multicolumn{5}{|c|}{ BA $(\mathrm{mg} / \mathrm{L})$} \\
\hline \multicolumn{2}{|c|}{0.1} & 1.19 & 100.00 & 1.39 \\
\hline \multicolumn{2}{|c|}{0.3} & 0.00 & 100.00 & 2.38 \\
\hline \multicolumn{2}{|c|}{0.5} & 0.00 & 98.81 & 9.72 \\
\hline \multicolumn{2}{|c|}{ Tukey HSD (\% 5) } & Ö.D & Ö.D & Ö.D \\
\hline \multicolumn{5}{|c|}{$\mathrm{GA}_{3}(\mathrm{mg} / \mathrm{L})$} \\
\hline \multicolumn{2}{|c|}{0} & 0.00 & 100.00 & 5.16 \\
\hline \multicolumn{2}{|c|}{0.05} & 1.19 & 100.00 & 7.14 \\
\hline \multicolumn{2}{|c|}{0.1} & 0.00 & 100.00 & 1.19 \\
\hline \multicolumn{2}{|c|}{ Tukey HSD (\% 5) } & Ö.D & Ö.D & Ö.D \\
\hline
\end{tabular}

Varyans analizi önemli bulunan uygulamaların aynı sütundaki ortalamaları arasındaki farklılıklar, Tukey testiyle $\mathrm{P} \leq 0.05$ 'e göre belirlenmiştir. ÖD: Önemli Değil

Meyvelerin dikilmesiyle oluşan ve serada yetiştirilen bitki sürgünlerinin gerçek yapraklarının kullanılmasıla kurulan 3. rejenerasyon denemesinden elde edilen ortalama değerler Çizelge 3'de verilmiştir. Bu denemede, yüzeysel dezenfeksiyon sırasında kullanılan sodyum hipoklorit konsantrasyonu \% 0.6 'dan \% 0.5'e azaltılarak $15 \mathrm{dk}$ olacak şekilde uygulanmıştır. Ayrıca denenen ortamlara 400 $\mathrm{mg} / \mathrm{L}$ sefotaksim sodyum eklenmiştir. $\mathrm{Bu}$ denemede yaprak eksplantları, çizilmeden MS ortamında BA ve NAA'nın farklı konsantrasyonları kombine edilerek oluşturulan ortamlarda kültüre alınmıştır. 1. rejenerasyon denemesinde uygulanan aynı dezenfeksiyon süresi ve sefotaksim sodyum konsantrasyonu sonucu kontaminasyon oran1 \% 10.07'den \% 6'ya düşürülmüştür. Denemede etkisi araştırılan faktörlerin ikili interaksiyonlarının, incelenen özelliklerden kallus ve kök oluşturan eksplant oranı bakımından önemli olduğu saptanmıştır (Çizelge 3). Ortama BA ve NAA eklenmediği durumda kallus oluşmadığı belirlenmiştir. Yapılan gözlemler doğrultusunda denenen konsantrasyonlardan $1 \mathrm{mg} / \mathrm{L}$ BA içeren MS ortamında çok düşük oranda yeşil kallus oluştuğu gözlenmiştir. Ancak diğer kombinasyonlarda ağırlıklı olarak beyaz kallus elde edilmiş olmakla birlikte, oluşan beyaz ve yeşil kalluslar karardığı için bitki üretilememiștir. Bununla birlikte, ikili interaksiyonlardan BA bulunmayan $0.5,1$ ve $1.5 \mathrm{mg} / \mathrm{L}$ NAA konsantrasyonlarını içeren ortamlarda kök oluşumu gerçekleşmiştir. Ancak eksplantlardan oluşan köklerden sürgün elde edilememiştir. 
Çizelge 3. Dikenli kabak meyvelerinden gelen serada yetiştirilen sürgünlerin gerçek yaprakları, 400 $\mathrm{mg} / \mathrm{L}$ sefotaksim sodyum ve farklı BA ve NAA konsantrasyonu bulunan ortamlarda kültüre alınması sonucu elde edilen ortalama değerler

\begin{tabular}{|c|c|c|c|c|c|}
\hline $\begin{array}{c}\text { BA } \\
(\mathrm{mg} / \mathrm{L})\end{array}$ & $\begin{array}{l}\text { NAA } \\
(\mathrm{mg} / \mathrm{L})\end{array}$ & $\begin{array}{l}\text { Kontamine olan } \\
\text { eksplant oran1 (\%) }\end{array}$ & $\begin{array}{c}\text { Canlı kalan } \\
\text { eksplant } \\
\text { oranı }(\%)\end{array}$ & $\begin{array}{c}\text { Kallus } \\
\text { oluşturan } \\
\text { eksplant oranı } \\
(\%)\end{array}$ & $\begin{array}{l}\text { Kök oluşturan } \\
\text { eksplant oranı (\%) }\end{array}$ \\
\hline 0 & 0 & 4.17 & 95.83 & $0.00^{\mathrm{d}}$ & $0.00^{\mathrm{b}}$ \\
\hline 0 & 0.5 & 0.00 & 100.00 & $4.17^{\mathrm{d}}$ & $16.67^{\mathrm{a}}$ \\
\hline 0 & 1 & 16.67 & 83.33 & $50.00^{\mathrm{b}}$ & $20.83^{a}$ \\
\hline 0 & 1.5 & 16.67 & 83.33 & $29.17^{\mathrm{bc}}$ & $16.67^{\mathrm{a}}$ \\
\hline 0.5 & 0 & 0.00 & 100.00 & $16.67^{\mathrm{cd}}$ & $0.00^{\mathrm{b}}$ \\
\hline 0.5 & 0.5 & 0.00 & 100.00 & $91.67^{\mathrm{a}}$ & $0.00^{\mathrm{b}}$ \\
\hline 0.5 & 1 & 0.00 & 100.00 & $100.00^{\mathrm{a}}$ & $0.00^{\mathrm{b}}$ \\
\hline 0.5 & 1.5 & 8.33 & 91.67 & $100.00^{\mathrm{a}}$ & $0.00^{\mathrm{b}}$ \\
\hline 1 & 0 & 0.00 & 100.00 & $100.00^{\mathrm{a}}$ & $0.00^{\mathrm{b}}$ \\
\hline 1 & 0.5 & 4.17 & 95.83 & $100.00^{\mathrm{a}}$ & $0.00^{\mathrm{b}}$ \\
\hline 1 & 1 & 0.00 & 100.00 & $100.00^{\mathrm{a}}$ & $0.00^{\mathrm{b}}$ \\
\hline 1 & 1.5 & 0.00 & 100.00 & $100.00^{\mathrm{a}}$ & $0.00^{\mathrm{b}}$ \\
\hline 1.5 & 0 & 4.17 & 95.83 & $100.00^{\mathrm{a}}$ & $0.00^{\mathrm{b}}$ \\
\hline 1.5 & 0.5 & 8.33 & 91.67 & $100.00^{\mathrm{a}}$ & $0.00^{\mathrm{b}}$ \\
\hline 1.5 & 1 & 16.67 & 83.33 & $100.00^{\mathrm{a}}$ & $0.00^{\mathrm{b}}$ \\
\hline 1.5 & 1.5 & 16.67 & 83.33 & $100.00^{\mathrm{a}}$ & $0.00^{\mathrm{b}}$ \\
\hline Tukey H & $\mathrm{SD}(\% 5)$ & Ö.D & Ö.D & 4.19 & 3.22 \\
\hline \multicolumn{6}{|c|}{ BA $(\mathrm{mg} / \mathrm{L})$} \\
\hline & & 9.38 & 90.63 & $20.83^{c}$ & $13.54^{\mathrm{a}}$ \\
\hline & & 2.08 & 91.67 & $77.08^{\mathrm{b}}$ & $0.00^{\mathrm{b}}$ \\
\hline & & 1.04 & 91.67 & $100.00^{\mathrm{a}}$ & $0.00^{\mathrm{b}}$ \\
\hline & & 11.46 & 95.83 & $100.00^{\mathrm{a}}$ & $0.00^{\mathrm{b}}$ \\
\hline Tukey $\mathrm{H}$ & $\mathrm{SD}(\% 5)$ & Ö.D & Ö.D & 7.88 & 6.05 \\
\hline \multicolumn{6}{|c|}{ NAA (mg/L) } \\
\hline & & 2.08 & 97.92 & $54.17^{\mathrm{c}}$ & 0.00 \\
\hline & & 3.13 & 96.88 & $73.96^{\mathrm{b}}$ & 4.17 \\
\hline & & 8.33 & 91.67 & $87.50^{\mathrm{a}}$ & 5.21 \\
\hline & & 10.42 & 89.58 & $82.29^{\mathrm{ab}}$ & 4.17 \\
\hline Tukey H & $\mathrm{SD}(\% 5)$ & Ö.D & Ö.D & 7.88 & Ö.D \\
\hline
\end{tabular}

Varyans analizi önemli bulunan uygulamaların aynı sütundaki ortalamaları arasındaki farklı1ıklar, Tukey testiyle $\mathrm{P} \leq 0.05$ 'e göre belirlenmiştir. ÖD: Önemli Değil

Sürgün ucu ve tomurcuk rejenerasyonu çalışmaları

Dikenli kabağın in vitro çoğaltılmasında kullanılacak sürgün ucu ve tomurcukların dezenfeksiyonu için uygun bir yöntemin belirlenmesi amacıyla yürütülen ilk çalışmadan elde edilen sonuçlar Çizelge 4'de sunulmuştur. Dezenfeksiyon süresinin, incelenen gözlemler üzerine etkisi istatiksel açıdan önemli bulunmamıştır. Ancak $15 \mathrm{dk}$ uygulanan \% 0.5 'lik sodyum hipoklorit çözeltisinde kontamine olan eksplant oran 1 (\% 35), $10 \mathrm{dk}$ 'l1k uygulama oranına (\% 60) göre daha düşük olmuştur. Bununla birlikte $15 \mathrm{dk}$ 'llk sodyum hipoklorit uygulamasının, eksplantlarda sürme oranında azalmaya neden olduğu ve kontaminasyonun çoğunlukla endojenik bakterilerden kaynaklandığı değerlendirilmiştir. $\mathrm{Bu}$ nedenlerle, sonraki denemelerde dezenfeksiyon protokolünde değişikliğe gidilmiştir. 


\section{Dikenli Kabağın In Vitro Rejenerasyonu Üzerine Çalışmalar}

Birinci dezenfeksiyon protokolü ( $\%$ 0.5'lik sodyum hipokloritte $15 \mathrm{dk}$.) uygulanarak sürgün ucu ve tomurcukların rejenerasyonu üzerine BA'nın etkisi incelendiğinde, sürgün oluşturma ortamında sürme oranı ve kardeşlendirme ortamında eksplant başına oluşan kardeş sayısının istatiksel olarak önemli olmadığ 1 belirlenmiştir (Çizelge 5). Bununla birlikte elde edilen sürgünler $0.5 \mathrm{mg} / \mathrm{L} \quad \mathrm{BA}$ içeren kardeşlendirme ortamına alınarak kardeş sayıları belirlenmiştir. En yüksek eksplant başına oluşan kardeş sayısı (3.75 adet), 0.3 $\mathrm{mg} / \mathrm{L}$ BA uygulamasindan gelen eksplantlarda belirlenmiştir. $\mathrm{Bu}$ denemde oluşan en yüksek kardeş say1s1, Sweetly ve ark. (2018)'nın elde ettiği en yüksek kardeş sayısından (4.89 adet/boğum) düşük olmuştur.

Çizelge 4. Dikenli kabakta sürgün ucu ve tomurcuklara MS ortamında uygulanan farklı dezenfeksiyon sürelerinin etkisi

\begin{tabular}{cc}
\hline $\begin{array}{c}\% .5^{\prime} \text { lik sodyum hipokloritte } \\
\text { dezenfeksiyon süresi (dk) }\end{array}$ & $\begin{array}{c}\text { Kontamine olan } \\
\text { eksplant oran }(\%)\end{array}$ \\
\hline 15 & 35.00 \\
10 & 60.00 \\
Tukey HSD (\% 5) & Ö.D \\
\hline
\end{tabular}

ÖD: Önemli Değil

Çizelge 5. Dikenli kabakta sürgün oluşturma ortamında farklı BA konsantrasyonu içeren MS ortamlarından gelen sürgünlerin $0.5 \mathrm{mg} / \mathrm{L} \mathrm{BA}$ içeren kardeşlendirme ortamında elde edilen kardeş say1ları

\begin{tabular}{cccc}
\hline $\begin{array}{c}\text { Sürgün oluşturma } \\
\text { ortamında BA içeriği } \\
(\mathrm{mg} / \mathrm{L})\end{array}$ & $\begin{array}{c}\text { Sürgün oluşturma ortamında } \\
\text { kontamin olmayan } \\
\text { eksplantlarda sürme oran }(\%)\end{array}$ & $\begin{array}{c}\text { Kardeşlendirme } \\
\text { ortamında BA } \\
\text { içeriği (mg/L) }\end{array}$ & $\begin{array}{c}\text { Kardeşlendirme } \\
\text { ortamında eksplant } \\
\text { başına oluşan } \\
\text { kardeş sayısı (adet) }\end{array}$ \\
\hline 0 & 8.33 & 0.5 & 0.00 \\
0.1 & 25.00 & 0.5 & 0.33 \\
0.3 & 50.00 & 0.5 & 3.75 \\
0.5 & 5.00 & 0.5 & 1.00 \\
Tukey HSD $(\% 5)$ & Ö.D & & Ö.D \\
\hline
\end{tabular}

ÖD: Önemli Değil

Sürgün ucu ve tomurcuk çalışmalarında birinci denemede uygulanan dezenfeksiyon protokolü sonucunda enfeksiyonun yüksek çıkması nedeniyle, kurulan ikinci denemede eksplantlar $\%$ 70'lik etil alkolde 15 sn ve ardından \% 0.75 'lik sodyum hipoklorit çözeltisinde $15 \mathrm{dk}$ bekletilerek yüzeysel dezenfeksiyon işlemi gerçekleştirilmiştir. Ayrıca endojenik bakteri kontaminasyonunu önlemek için ortama 400 $\mathrm{mg} / \mathrm{L}$ sefotaksim sodyum eklenmiştir. Bu denemede kontamine olan eksplant oran1 (ortalama \% 3.75), birinci denemede oluşan kontaminasyon oranından (ortalama \% 47.5) oldukça düşük olduğundan, dezenfeksiyon protokolünün etkili olduğu görülmektedir. Ancak burada tüm ortamlara sefotaksim sodyum eklendiğinden kontaminasyon oranının düşük çıkması, sefotaksim sodyum kullanımıyla ilişkili olabileceği belirtilebilir. Ayrıca bu denemede oluşan sürgünlerde sararma olduğu görülmüşsür. Bunun nedeninin dezenfeksiyon sirasinda etil alkol ve sodyum hipoklorit konsantrasyonları ve uygulama sürelerinden kaynaklanmış olabileceği değerlendirilmiştir. İkinci dezenfeksiyon protokolü uygulanarak kurulan 2. denemede, eksplantların rejenerasyonu için MS temel ortamında $\mathrm{BA}$ ve $\mathrm{GA}_{3}$ 'ün etkisi incelenmiştir (Çizelge 6). İncelenen özelliklerin tümünde "BA x $\mathrm{GA}_{3}$ " ikili interaksiyonlarının etkisi, istatiksel olarak önemsiz bulunmuştur. Ana faktörlerden BA konsantrasyon uygulamasının, canlı kalan eksplant oranına etkisinin önemli olduğu, sürme oranına etkisinin ise önemsiz olduğu belirlenmiştir. Ancak, dikenli kabak bitkisinde yapılan çalışmada embriyoların 0.5 $\mathrm{mg} / \mathrm{L}$ BA içeren ortamda kültüre alınması sonucu, sürgün elde edildiği bildirilmiştir (Abdelnour ve Engelmann, 2002a). Çalışmamızda ana faktör olarak $\mathrm{GA}_{3}$ 'ün etkisi incelendiğinde ise istatiksel olarak önemsiz olduğu bulunmuştur. 
Çizelge 6. Dikenli kabakta sürgün ucu ve tomurcuklara $400 \mathrm{mg} / \mathrm{L}$ sefotaksim sodyum içeren ortamda uygulanan farklı BA ve $\mathrm{GA}_{3}$ konsantrasyonları sonucu elde edilen ortalama değerler

\begin{tabular}{|c|c|c|c|}
\hline $\begin{array}{c}\text { BA } \\
(\mathrm{mg} / \mathrm{L})\end{array}$ & $\begin{array}{c}\mathrm{GA}_{3} \\
(\mathrm{mg} / \mathrm{L})\end{array}$ & $\begin{array}{l}\text { Canlı } \\
\text { kalan } \\
\text { eksplant } \\
\text { oranı } \\
(\%)\end{array}$ & $\begin{array}{c}\text { Kontamine } \\
\text { olmayan } \\
\text { eksplantlarda } \\
\text { sürme oranı }(\%)\end{array}$ \\
\hline 0 & 0 & 80.00 & 6.25 \\
\hline 0.5 & 0 & 100.00 & 20.00 \\
\hline 0.75 & 0 & 100.00 & 5.00 \\
\hline 1 & 0 & 100.00 & 15.00 \\
\hline 0 & 0.5 & 90.00 & 11.25 \\
\hline 0.5 & 0.5 & 100.00 & 5.00 \\
\hline 0.75 & 0.5 & 100.00 & 30.00 \\
\hline 1 & 0.5 & 100.00 & 5.00 \\
\hline Tukey I & $\mathrm{SD}(\% 5)$ & Ö.D & Ö.D \\
\hline \multicolumn{4}{|c|}{ BA $(\mathrm{mg} / \mathrm{L})$} \\
\hline & 0 & $85.00^{\mathrm{b}}$ & 8.75 \\
\hline & .5 & $100.00^{\mathrm{a}}$ & 12.50 \\
\hline & 75 & $100.00^{\mathrm{a}}$ & 17.50 \\
\hline & 1 & $100.00^{\mathrm{a}}$ & 10.00 \\
\hline Tukey I & $\mathrm{SD}(\% 5)$ & 9.97 & Ö.D \\
\hline \multicolumn{4}{|c|}{$\mathrm{GA}_{3}(\mathrm{mg} / \mathrm{L})$} \\
\hline & 0 & 95.00 & 11.56 \\
\hline & .5 & 97.50 & 12.81 \\
\hline Tukey I & $\mathrm{SD}(\% 5)$ & Ö.D & Ö.D \\
\hline
\end{tabular}

Varyans analizi önemli bulunan uygulamaların aynı sütundaki ortalamaları arasındaki farklılıklar, Tukey testiyle $\mathrm{P} \leq 0.05$ 'e göre belirlenmiştir. ÖD: Önemli Değil

Söz konusu 2. denemede, sürgün ucu ve tomurcuklarına uygulanan $\mathrm{BA}$ ve $\mathrm{GA}_{3}$ kombinasyonlarından elde edilen bitkilerin kardeşlenme durumlarının incelenmesi amacıyla $\mathrm{GA}_{3}$ içermeyen aynı BA konsantrasyonuna sahip MS ortamlarına aktarılarak, eksplant başına oluşan kardeş sayıları belirlenmiştir (Çizelge 7). Elde edilen sonuçlara göre farklı BA ve $\mathrm{GA}_{3}$ kombinasyonlarından gelen eksplantlarda, eksplant başına meydana gelen kardeş sayısının istatiksel olarak önemli olmadığı tespit edilmiştir. Bununla birlikte, 0.75 veya $1 \mathrm{mg} / \mathrm{L}$ BA içeren sürgün oluşturma ortamından gelen eksplantların yine aynı BA konsantrasyonuna alınması sonucu, diğer uygulamalara kıyasla daha yüksek kardeş sayısı oluştuğu belirlenmiştir. $\mathrm{Bu}$ denemde oluşan en yüksek kardeş sayısı (1.65 adet/eksplant), Sweetly ve ark. (2018)'nın elde ettiği kardeş sayısından
(4.89 adet/boğum) daha düşük olmuștur. İki deneme arasındaki farklılık, kullanılan genotipten ve/veya bitki büyüme düzenleyici kombinasyonunun farklılığından kaynaklanmış olabilir.

Çizelge 7. Dikenli kabakta sürgün oluşturma ortamında farkl1 BA ve $\mathrm{GA}_{3}$ kombinasyonu ve $400 \mathrm{mg} / \mathrm{L}$ sefotaksim sodyum içeren MS ortamlarından gelen sürgünlerin, aynı konsantrasyon sefotaksim sodyumla birlikte farklı BA içeren kardeşlendirme ortamlarında elde edilen kardeş sayıları

\begin{tabular}{ccc}
\hline $\begin{array}{c}\text { Sürgün oluşturma } \\
\text { ortamında BA ve } \\
\mathrm{GA}_{3} \text { içeriği }\end{array}$ & $\begin{array}{c}\text { Kardeşlendirme } \\
\text { ortamında BA } \\
\text { içeriği }(\mathrm{mg} / \mathrm{L})\end{array}$ & $\begin{array}{c}\text { Eksplant başına } \\
\text { oluşan kardeş } \\
\text { sayısı (adet) }\end{array}$ \\
\hline 0 & 0 & 0.12 \\
$0.5 \mathrm{mg} / \mathrm{L} \mathrm{BA}$ & 0.5 & 1.10 \\
$0.75 \mathrm{mg} / \mathrm{L} \mathrm{BA}$ & 0.75 & 1.60 \\
$1 \mathrm{mg} / \mathrm{L} \mathrm{BA}$ & 1 & 1.65 \\
$0.5 \mathrm{mg} / \mathrm{L} \mathrm{GA}{ }_{3}$ & 0 & 0.00 \\
$0.5 \mathrm{mg} / \mathrm{L} \mathrm{BA}+$ & & \\
$0.5 \mathrm{mg} / \mathrm{L} \mathrm{GA}{ }_{3}$ & 0.5 & 0.10 \\
$0.75 \mathrm{mg} / \mathrm{L} \mathrm{BA}+$ & 0.75 & 1.50 \\
$0.5 \mathrm{mg} / \mathrm{L} \mathrm{GA} \mathrm{H}_{3}$ & & \\
$1 \mathrm{mg} / \mathrm{L} \mathrm{BA}+$ & & 0.45 \\
$0.5 \mathrm{mg} / \mathrm{L} \mathrm{GA} \mathrm{B}_{3}$ & 1 & Ö.D \\
Tukey HSD $(\%$ 5) & &
\end{tabular}

ÖD: Önemli Değil

Kurulan 2. denemedeki bitkilerin sararmasindan dolayı, dezenfeksiyon sirasinda uygulanacak \% 70'lik etil alkolün uygulama süresi ve sodyum hipoklorit oranının azaltılması gerektiği değerlendirilmiştir. Buna uygun olarak kurulan 3. denemede eksplantlar, \% 70 etil alkolde 5 sn ve \% 0.60 sodyum hipoklorit çözeltisinde $15 \mathrm{dk}$ bekletilmiştir. Ayrıca ortamlara 0 veya $400 \mathrm{mg} / \mathrm{L}$ sefotaksim sodyum eklenmiştir. $\mathrm{Bu}$ denemede sefotaksim sodyumun etkisi incelenmiştir ve MS temel besi ortamında BA'nın farklı konsantrasyonları denenmiştir. Uygulamadan elde edilen değerler Çizelge 8'de verilmiştir. Sefotaksim sodyumun, incelenen tüm özellikler üzerine etkisi istatiksel anlamda önemli bulunmuştur. Ortama sefotaksim sodyum eklenmediğinde eksplantların \% 51.25'i kontamine olmuştur. Sefotaksim sodyum uygulamasi sonucu ise kontamine olan eksplant oran1 \% 12.50 'ye düşmüş ve süren eksplant oranı $\% 6.25$ 'ten $\%$ 31.25 'e yükselmiştir. In vivo ortamda yetiştirilen dikenli kabak bitkilerinin 
dezenfeksiyonunda, endojenik bakteri kontaminasyonlarının makul düzeye indirilmesi için bu denemede uygulanan dezenfeksiyon protokolüne ek olarak, özellikle rejenerasyon besi ortamlarına $400 \mathrm{mg} / \mathrm{L}$ sefotaksim sodyum eklenmesinin uygun olacağı belirlenmiştir. Ayrıca, eksplant başına oluşan kardeş sayısı bakımindan "sefotaksim sodyum x BA" interaksiyonunun istatistiksel açıdan önemli olduğu belirlenmiştir (Çizelge 8). Burada 400 $\mathrm{mg} / \mathrm{L}$ sefotaksim sodyum uygulamas i ile BA'nın 0.5 veya $0.75 \mathrm{mg} / \mathrm{L}$ konsantrasyonları uygulandığında en yüksek kardeş sayısı (sirasiyla 1.45, 1.15 adet/eksplant) elde edilmiştir.

Çizelge 8. Dikenli kabakta sürgün ucu ve tomurcuklara, sürgün oluşturma ortamında uygulanan farklı BA ve sefotaksim sodyum konsantrasyonlarının kontaminasyon, sürme ve kardeşlenme üzerine etkisi

\begin{tabular}{|c|c|c|c|c|c|}
\hline $\begin{array}{l}\text { Sefotaksim } \\
\text { sodyum } \\
(\mathrm{mg} / \mathrm{L})\end{array}$ & $\begin{array}{c}\mathrm{BA} \\
(\mathrm{mg} / \mathrm{L})\end{array}$ & $\begin{array}{l}\text { Kontamine } \\
\text { olan eksplant } \\
\text { oran1 (\%) }\end{array}$ & $\begin{array}{c}\text { Canlı kalan } \\
\text { eksplant } \\
\text { oran1 (\%) }\end{array}$ & $\begin{array}{c}\text { Kontamine } \\
\text { olmayan } \\
\text { eksplantlarda } \\
\text { sürme oran1 }(\%) \\
\end{array}$ & $\begin{array}{c}\text { Eksplant başına } \\
\text { oluşan kardeş sayıs1 } \\
\text { (adet) }\end{array}$ \\
\hline 0 & 0 & 30.00 & 70.00 & 0.00 & $0.00^{\mathrm{b}}$ \\
\hline 0 & 0.5 & 75.00 & 25.00 & 25.00 & $0.00^{\mathrm{b}}$ \\
\hline 0 & 0.75 & 60.00 & 40.00 & 0.00 & $0.00^{\mathrm{b}}$ \\
\hline 0 & 1 & 40.00 & 60.00 & 0.00 & $0.00^{\mathrm{b}}$ \\
\hline 400 & 0 & 0.00 & 100.00 & 15.00 & $0.10^{\mathrm{ab}}$ \\
\hline 400 & 0.5 & 25.00 & 75.00 & 50.00 & $1.45^{\mathrm{a}}$ \\
\hline 400 & 0.75 & 0.00 & 100.00 & 40.00 & $1.15^{\mathrm{a}}$ \\
\hline 400 & 1 & 25.00 & 75.00 & 20.00 & $0.10^{\mathrm{ab}}$ \\
\hline \multicolumn{2}{|c|}{ Tukey HSD (\% 5) } & Ö.D & Ö.D & Ö.D & 0.12 \\
\hline \multicolumn{6}{|c|}{$\mathrm{BA}(\mathrm{mg} / \mathrm{L})$} \\
\hline \multicolumn{2}{|c|}{0} & 15.00 & 85.00 & 7.50 & 0.05 \\
\hline \multicolumn{2}{|c|}{0.5} & 50.00 & 50.00 & 37.50 & 0.73 \\
\hline \multicolumn{2}{|c|}{0.75} & 30.00 & 70.00 & 20.00 & 0.58 \\
\hline \multicolumn{2}{|c|}{1} & 32.50 & 67.50 & 10.00 & 0.05 \\
\hline \multicolumn{2}{|c|}{ Tukey HSD (\% 5) } & Ö.D & Ö.D & Ö.D & Ö.D \\
\hline \multicolumn{6}{|c|}{ Sefotaksim sodyum (mg/L) } \\
\hline \multicolumn{2}{|c|}{0} & $51.25^{\mathrm{a}}$ & $48.75^{\mathrm{b}}$ & $6.25^{\mathrm{b}}$ & $0.00^{\mathrm{b}}$ \\
\hline \multicolumn{2}{|c|}{400} & $12.50^{\mathrm{b}}$ & $87.50^{\mathrm{a}}$ & $31.25^{\mathrm{a}}$ & $0.70^{\mathrm{a}}$ \\
\hline \multicolumn{2}{|c|}{ Tukey HSD (\% 5) } & 20.94 & 20.94 & 14.95 & 0.17 \\
\hline
\end{tabular}

Varyans analizi önemli bulunan uygulamaların aynı sütundaki ortalamaları arasındaki farklılıklar, Tukey testiyle $\mathrm{P} \leq 0.05$ 'e göre belirlenmiştir. ÖD: Önemli Değil

Sürgün ucu ve tomurcuk eksplantlarının kullanıldığı son denemede en uygun dezenfeksiyon yöntemiyle, en başarılı BA konsantrasyonları ve $\mathrm{GA}_{3}$ kombine edilerek rejenerasyon denemesi tekrar edilmiştir. $\mathrm{Bu}$ amaçla, serada yetiştirilen bitkilerin sürgün ucu ve yaprak koltuklarından alınan tomurcuk eksplantlar1, \% 0.60 sodyum hipoklorit konsantrasyonunda $15 \mathrm{dk}$ bekletilerek yüzeysel dezenfeksiyon işlemi gerçekleştirilmiştir. Ve kullanılan besi ortamlarına $400 \mathrm{mg} / \mathrm{L}$ sefotaksim sodyum" eklenmiştir. Uygulanan dezenfeksiyon yöntemi ve ortamlara $400 \mathrm{mg} / \mathrm{L}$ sefotaksim sodyum eklenmesiyle kontaminasyonun $\% \quad 0.0$ ila 5.0 arasinda değiştiği saptanmıştır (Çizelge 9). Bu denemede uygulanan $\mathrm{BA}$ ve $\mathrm{GA}_{3}$ 'ün, kallus oluşturan eksplant oranı hariç incelenen özellikler üzerine istatistiksel olarak etkili olmadığ (Çizelge 9). Ayrıca, $0.5 \mathrm{mg} / \mathrm{L} \mathrm{GA} 3$ içeren ortamlara kıyasla $\mathrm{GA}_{3}$ 'ün eklenmediği ortamlarda daha yüksek oranda (\% 48.75) kallus oluştuğu tespit edilmiştir. Buradan elde edilen sonuca göre $\mathrm{GA}_{3}$ uygulanan bitkilerde kallus oluşumunun daha az oranda (\% 20.00) gerçekleştiği saptanmıştır. Yapılan gözlemler neticesinde bu ortamlarda 2 hafta kalan eksplantlarda $\mathrm{GA}_{3}$ 'den dolay1 sararma 


\section{Dikenli Kabağın In Vitro Rejenerasyonu Üzerine Çalışmalar}

görüldüğünden (Şekil 2), eksplantlar yalnızca BA içeren ortamlara alınmıştır. Söz konusu eksplantlar (k1sa sürgünler), bu ortamlarda kültüre alındıktan sonra sararmanın azaldığ1 tespit edilmiştir.

Çizelge 9. Dikenli kabakta sürgün ucu ve tomurcuklara $400 \mathrm{mg} / \mathrm{L}$ sefotaksim sodyum içeren sürgün oluşturma ortamında uygulanan farklı BA ve $\mathrm{GA}_{3}$ uygulaması sonucu elde edilen değerler

\begin{tabular}{|c|c|c|c|c|c|}
\hline $\mathrm{BA}(\mathrm{mg} / \mathrm{L})$ & $\mathrm{GA}_{3}(\mathrm{mg} / \mathrm{L})$ & $\begin{array}{l}\text { Kontamine } \\
\text { olan eksplant } \\
\text { oran1 }(\%)\end{array}$ & $\begin{array}{c}\text { Canlı kalan } \\
\text { eksplant } \\
\text { oranı }(\%)\end{array}$ & $\begin{array}{c}\text { Kontamine olmayan } \\
\text { eksplantlarda sürme } \\
\text { oran }(\%)\end{array}$ & $\begin{array}{c}\text { Kallus } \\
\text { oluşturan } \\
\text { eksplant oranı } \\
(\%)\end{array}$ \\
\hline 0.5 & 0 & 5.00 & 95.00 & 82.50 & 37.50 \\
\hline 0.75 & 0 & 0.00 & 100.00 & 85.00 & 60.00 \\
\hline 0.5 & 0.5 & 0.00 & 100.00 & 85.00 & 15.00 \\
\hline 0.75 & 0.5 & 0.00 & 100.00 & 90.00 & 25.00 \\
\hline Tukey $\mathrm{H}$ & $\mathrm{SD}(\% 5)$ & Ö.D & Ö.D & Ö.D & Ö.D \\
\hline \multicolumn{6}{|c|}{$\mathrm{BA}(\mathrm{mg} / \mathrm{L})$} \\
\hline & .5 & 2.50 & 97.50 & 83.75 & 26.25 \\
\hline & 75 & 0.00 & 100.00 & 87.50 & 42.50 \\
\hline Tukey $\mathrm{H}$ & $\mathrm{SD}(\% 5)$ & Ö.D & Ö.D & Ö.D & Ö.D \\
\hline \multicolumn{6}{|c|}{$\mathrm{GA}_{3}(\mathrm{mg} / \mathrm{L})$} \\
\hline & 0 & 2.50 & 97.50 & 83.75 & $48.75^{a}$ \\
\hline & .5 & 0.00 & 100.00 & 87.50 & $20.00^{b}$ \\
\hline Tukey $\mathrm{H}$ & $\mathrm{SD}(\% 5)$ & Ö.D & Ö.D & Ö.D & 13.25 \\
\hline
\end{tabular}

Varyans analizi önemli bulunan uygulamaların aynı sütundaki ortalamaları arasındaki farkl11ıklar, Tukey testiyle $\mathrm{P} \leq 0.05$ 'e göre belirlenmiştir. ÖD: Önemli Değil

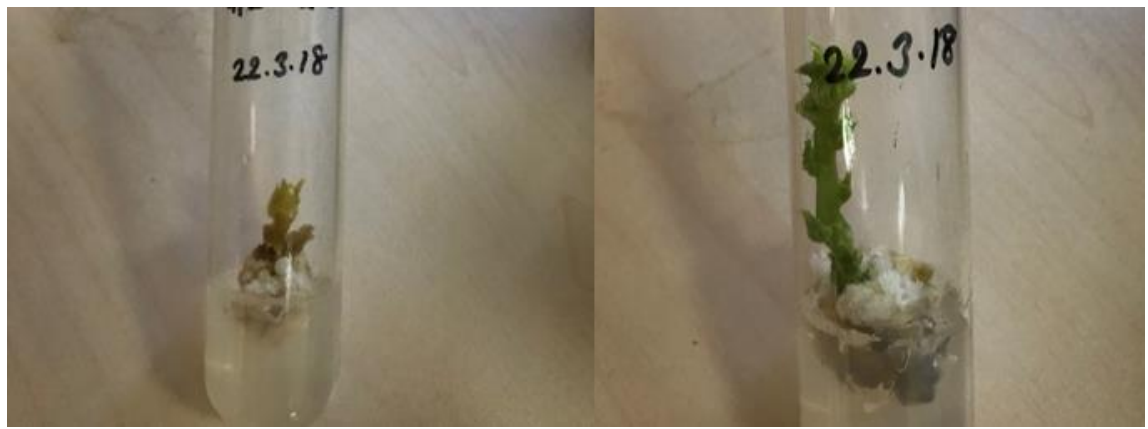

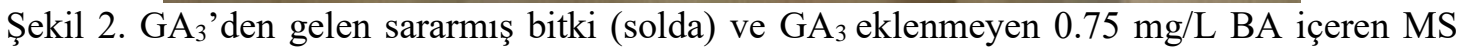
ortamında gelişen yeşil sürgün (sağda)

Sürgün ucu ve gövde tomurcukları kullanılarak kurulan 1., 2. ve 3. denemelerden elde edilen sürgünlerle birinci köklendirme denemesi kurulmuştur. $\mathrm{Bu}$ denemede, MS ortamında NAA'nın farklı konsantrasyonları denenmiştir. Kurulan köklendirme denemesinde kullanılan bitkiler, $0.5 \mathrm{mg} / \mathrm{L} \mathrm{BA}$ içeren sürgün oluşturma ortamindan gelen bitkilerdir. Denenen NAA konsantrasyonlarının, incelenen özelliklerden sadece kök uzunluğu üzerine olan etkisi istatiksel açıdan önemli bulunmuştur (Çizelge 10). Denenen NAA konsantrasyonlarından 0.2 $\mathrm{mg} / \mathrm{L}$ konsantrasyonunda oluşan kökler, kontrole göre daha uzun olmuștur. Kallus oluşturan bitki oranı özellikleri bakımından, 0.1 $\mathrm{mg} / \mathrm{L}$ NAA içeren ortam ile $0.2 \mathrm{mg} / \mathrm{L}$ NAA' 1 ortam arasındaki fark istatistiksel olarak önemli olmasa da, $0.1 \mathrm{mg} / \mathrm{L}$ NAA bulunan ortamda daha yüksek ortalama değerler elde edilmiştir. Elde edilen in vitro fidelerin dış koșullara aktarılması sırasında bitkilerin çok azı dış koşullara alışmış ve bitkiye dönüşmüştür. Ancak, oluşan rejenerantların nemli torbalara aktarilmasi ve kademeli olarak nemin azaltılması sonucu dış koşullara aklime olan bitkilerin oranı yükselmiş ve bazı uygulamalarda ortalama \% 58.33'e yükselmiştir 


\section{Dikenli Kabağın In Vitro Rejenerasyonu Üzerine Çalışmalar}

(Çizelge 10). Bu şekilde üretilen bitkilerde yapılan ploidi analizi sonucunda, rejenerantlar arasında ploidi açısından varyasyon belirlenmemiş olup, üretilen bitkilerin diploid olduğu saptanmıştır.

Çizelge 10. Dikenli kabakta $0.5 \mathrm{mg} / \mathrm{L}$ BA içeren sürgün oluşturma ortamından gelen sürgünlerin $400 \mathrm{mg} / \mathrm{L}$ sefotaksim sodyum ve farklı NAA konsantrasyonu bulunan ortamlarda kültüre alınmas1 ve oluşan bitkilerin saksıya aktarılması sonucu elde edilen ortalama değerler

\begin{tabular}{ccccccccc}
\hline NAA & $\begin{array}{c}\text { Canl1 } \\
\text { kalan } \\
\text { eksplan } \\
\text { t oran1 } \\
(\%)\end{array}$ & $\begin{array}{c}\text { Kallus } \\
\text { oluştura } \\
\text { n bitki } \\
\text { oran1 } \\
(\%)\end{array}$ & $\begin{array}{c}\text { Kök } \\
\text { oluştura } \\
\text { n bitki } \\
\text { oran1 } \\
(\%)\end{array}$ & $\begin{array}{c}\text { Ortalam } \\
\text { a kök } \\
\text { uzunlug } \\
\text { u }(\mathrm{cm})\end{array}$ & $\begin{array}{c}\text { Ortalam } \\
\text { a kök } \\
\text { say1s1 } \\
(\text { adet })\end{array}$ & $\begin{array}{c}\text { Saksıya } \\
\text { aktar1la } \\
\text { n bitki } \\
\text { oran1 } \\
(\%)\end{array}$ & $\begin{array}{c}\text { Saks1d } \\
\text { a tutan } \\
\text { bitki } \\
\text { oran1 } \\
(\%)\end{array}$ & $\begin{array}{c}\text { Poliploi } \\
\text { d bitki } \\
\text { oran1 } \\
(\%)\end{array}$ \\
\hline 0 & 100.00 & 36.67 & 36.67 & $7.88^{\mathrm{b}}$ & 2.53 & 63.33 & 58.33 & 0.00 \\
0.1 & 93.33 & 71.11 & 71.11 & $9.86^{\text {ba }}$ & 2.62 & 87.78 & 56.67 & 0.00 \\
0.2 & 100.00 & 36.67 & 36.67 & $12.80^{\text {a }}$ & 3.28 & 83.33 & 45.00 & 0.00 \\
$\begin{array}{c}\text { Tukey HSD } \\
(\% ~ 5)\end{array}$ & Ö.D & Ö.D & Ö.D & 3.92 & Ö.D & Ö.D & Ö.D & Ö.D
\end{tabular}

Varyans analizi önemli bulunan uygulamaların aynı sütundaki ortalamaları arasındaki farklılıklar, Tukey testiyle $\mathrm{P} \leq 0.05$ 'e göre belirlenmiştir. ÖD: Önemli Değil

Daha önce kurulan 2. ve 3. sürgün ucu ve tomurcuk denemelerindeki $0.75 \mathrm{mg} / \mathrm{L}$ BA içeren sürgün oluşturma ortamından gelen sürgünler, ikinci köklendirme denemesinde kullanılmıştır. Çizelge 11'den anlaşılacağı gibi denenen farklı NAA konsantrasyonlarının saksıya aktarilan bitki oranı ve saksida tutan bitki oranı hariç diğer gözlemler üzerine etkisi istatiksel olarak önemli bulunmamıştır. En yüksek saksıya aktarılan bitki oranı (\% 86.67) ve saksıda tutan bitki oranı (\% 51.11) NAA'nın uygulanmadığı ortamda gerçekleşmiştir. Bu sonuçlar, uygulanan NAA konsantrasyonlarının köklenme üzerine etkili olmadı̆̆ını göstermektedir.

Çizelge 11. Dikenli kabakta $0.75 \mathrm{mg} / \mathrm{L}$ BA içeren sürgün oluşturma ortamından gelen sürgünlerin $400 \mathrm{mg} / \mathrm{L}$ sefotaksim sodyum ve farkl1 NAA konsantrasyonu bulunan ortamlarda kültüre alınmas1 ve oluşan bitkilerin saksıya aktarılması sonucu elde edilen ortalama değerler

\begin{tabular}{|c|c|c|c|c|c|c|c|c|}
\hline NAA (mg/L) & $\begin{array}{c}\text { Canlı } \\
\text { kalan } \\
\text { eksplant } \\
\text { oranı (\%, }\end{array}$ & $\begin{array}{c}\text { Kallus } \\
\text { oluşturan } \\
\text { bitki oran } \\
(\%)\end{array}$ & $\begin{array}{c}\text { Kök } \\
\text { oluşturan } \\
\text { bitki oran } \\
(\%)\end{array}$ & $\begin{array}{l}\text { Ortalama } \\
\text { kök } \\
\text { uzunluğu } \\
\text { (cm) }\end{array}$ & $\begin{array}{c}\text { Ortalama } \\
\text { kök say1s1 } \\
\text { (adet) }\end{array}$ & $\begin{array}{c}\text { Saksiya } \\
\text { aktarılan } \\
\text { bitki } \\
\text { oranı }(\%,\end{array}$ & $\begin{array}{l}\text { Saksida } \\
\text { tutan } \\
\text { bitki } \\
\text { oranı } \\
(\%)\end{array}$ & $\begin{array}{c}\text { Poliploid } \\
\text { bitki oranı } \\
(\%)\end{array}$ \\
\hline 0 & 100.00 & 73.33 & 66.67 & 9.77 & 2.00 & $86.67^{\mathrm{a}}$ & $51.11^{\mathrm{a}}$ & 0.00 \\
\hline 0.5 & 100.00 & 33.33 & 33.33 & 9.56 & 2.11 & $33.33^{b}$ & $0.00^{b}$ & 0.00 \\
\hline 1 & 100.00 & 38.89 & 45.56 & 8.42 & 1.67 & $75.56^{\mathrm{ab}}$ & $16.67^{\mathrm{ab}}$ & 0.00 \\
\hline $\begin{array}{c}\text { Tukey HSD } \\
(\% 5)\end{array}$ & Ö.D & Ö.D & Ö.D & Ö.D & Ö.D & 37.19 & 41.53 & Ö.D \\
\hline
\end{tabular}

Varyans analizi önemli bulunan uygulamaların aynı sütundaki ortalamaları arasındaki farklılıklar, Tukey testiyle $\mathrm{P} \leq 0.05$ 'e göre belirlenmiştir. ÖD: Önemli Değil

Bitkilerin köklendirilmesi için NAA'nın farklı konsantrasyonlarının denendiği 3. çalışmada; 1., 2. ve 3. sürgün ucu ve tomurcuk rejenerasyon denemelerinin $0.5 \mathrm{mg} / \mathrm{L}$ BA sürgün oluşturma uygulamasindan gelen köksüz sürgünler kullanılmıştır. Bu denemede NAA'nın dozları, 2. köklendirme denemesine göre azaltılmıştır
(Çizelge 12). Ayrıca denemede MS temel besin ortamının kontrol olarak kullanıldığ ortamlardan birine sadece sefotaksim sodyum eklenmemiştir. Burada amaç, sefotaksim sodyumun köklenme üzerine olan etkisini gözlemlemektir. MS temel ortamı ile sadece sefotaksim sodyum eklenen temel MS ortamı 


\section{Dikenli Kabağın In Vitro Rejenerasyonu Üzerine Çalışmalar}

arasında, istatiksel açıdan önemli fark olmamakla birlikte; kök oluşturan bitki oranı, ortalama kök uzunluğu ve kök sayısı, saksıya aktarılan bitki oranı ve saksıda tutan bitki oranı bakımindan ortama sefotaksim sodyum eklemenin olumlu etkileri görülmektedir. İncelenen özelliklerden kallus oluşturan ve kök oluşturan bitki oranı açısından, NAA/sefotaksim sodyum uygulamasının istatiksel olarak önemli olduğu bulunmuştur (Çizelge 12). Denemeye alınan NAA dozlarının, incelenen diğer gözlemler üzerine etkisinin olmadığ 1 görülmektedir. Kallus olușturan bitki oranı (\% 86.67), 0.01 veya 0.05 $\mathrm{mg} / \mathrm{L}$ NAA içeren sefotaksim sodyumlu uygulamalarda daha yüksek olmuştur. En yüksek kök oluşturan bitki oranı (\% 100) sefotaksim sodyum ve $0.05 \mathrm{mg} / \mathrm{L}$ NAA bulunan ortamdan elde edilmiştir (Çizelge 12). Köklenen bitki oranı, Wang ve ark. (1997)'nın dikenli kabakta bildirdiği köklendirme oranından daha yüksektir. Flow Sitometri analizi sonucu, çalışmamızdan elde edilen rejenerantlarin hepsi diploid olarak belirlenmiştir. In vitro rejenerasyon sonunda üretilen ve serada yetiştirilen bitkiler, bitki morfolojisi, meyve oluşumu ve ploidi seviyesi dikkate alınarak, rejenere olan bitkilerde somaklonal varyasyon meydana gelmediği değerlendirilebilir. Sürgün ucu ve tomurcuk eksplantlarının kullanıldığı son rejenerasyon denemesinde oluşan köksüz bitkicikler kullanılarak 4. köklendirme denemesi kurulmuştur. Denemede $0.75 \mathrm{mg} / \mathrm{L}$ BA ile 0.75 $\mathrm{mg} / \mathrm{L} \mathrm{BA}$ ve $0.5 \mathrm{mg} / \mathrm{L} \mathrm{GA}_{3}$ içeren ortamdan gelen eksplantlar kullanılmıştır. Denemeden elde edilen ortalama veriler Çizelge 13 'de verilmiştir İncelenen özelliklerden kallus oluşturan bitki oranı gözlemlerinde en yüksek değer, $0.07 \mathrm{mg} / \mathrm{L}$ NAA konsantrasyonundan elde edilmiştir. $\mathrm{Bu}$ köklendirme ortamında bitkilerin \% 100 'ü kallus, \% 53'ü kök oluşturmuştur. $\mathrm{Bu}$ denemede oluşan köklenme oran1, 3. denemden elde edilen orandan düşük olmuştur.

Çizelge 12. Dikenli kabakta $0.5 \mathrm{mg} / \mathrm{L}$ BA içeren sürgün oluşturma ortamından gelen sürgünlerin farklı NAA/sefotaksim sodyum konsantrasyonu bulunan ortamlarda kültüre alınması ve oluşan bitkilerin saksıya aktarılması sonucu elde edilen ortalama değerler

\begin{tabular}{|c|c|c|c|c|c|c|c|c|}
\hline $\begin{array}{l}\text { NAA/ } \\
\text { sefotaksim } \\
\text { sodyum } \\
\text { (mg/L) }\end{array}$ & $\begin{array}{c}\text { Canlı } \\
\text { kalan } \\
\text { eksplant } \\
\text { oran1 (\%) }\end{array}$ & $\begin{array}{c}\text { Kallus } \\
\text { oluşturan } \\
\text { bitki oranı } \\
(\%)\end{array}$ & $\begin{array}{c}\text { Kök } \\
\text { oluşturan } \\
\text { bitki oranı } \\
(\%)\end{array}$ & $\begin{array}{l}\text { Ortalama } \\
\text { kök } \\
\text { uzunluğu } \\
(\mathrm{cm})\end{array}$ & $\begin{array}{c}\text { Ortalama } \\
\text { kök sayısı } \\
\text { (adet) }\end{array}$ & $\begin{array}{c}\text { Saksiya } \\
\text { aktarılan } \\
\text { bitki oranı } \\
(\%)\end{array}$ & $\begin{array}{c}\text { Saksida } \\
\text { tutan } \\
\text { bitki } \\
\text { oran1 } \\
(\%) \\
\end{array}$ & $\begin{array}{l}\text { Poliploid } \\
\text { bitki oranı } \\
\text { (\%) }\end{array}$ \\
\hline $0.0 / 0.0$ & 100.00 & $0.00^{\mathrm{b}}$ & $73.33^{\mathrm{ab}}$ & 5.30 & 1.83 & 20.00 & 33.33 & 0.00 \\
\hline $0.0 / 400$ & 100.00 & $0.00^{\mathrm{b}}$ & $80.00^{a b}$ & 11.84 & 3.25 & 66.67 & 38.89 & 0.00 \\
\hline $0.01 / 400$ & 100.00 & $86.67^{\mathrm{a}}$ & $46.67^{\mathrm{b}}$ & 8.78 & 1.83 & 40.00 & 25.00 & 0.00 \\
\hline $0.05 / 400$ & 100.00 & $86.67^{\mathrm{a}}$ & $100.00^{\mathrm{a}}$ & 3.72 & 3.00 & 20.00 & 33.33 & 0.00 \\
\hline $\begin{array}{c}\text { Tukey HSD } \\
(\% 5)\end{array}$ & Ö.D & 25.30 & 27.38 & Ö.D & Ö.D & Ö.D & Ö.D & Ö.D \\
\hline
\end{tabular}

Varyans analizi önemli bulunan uygulamaların aynı sütundaki ortalamaları arasındaki farklılıklar, Tukey testiyle $\mathrm{P} \leq 0.05$ 'e göre belirlenmiştir. ÖD: Önemli Değil

Çizelge 13. Dikenli kabakta $0.75 \mathrm{mg} / \mathrm{L} \mathrm{BA}$ ile $0.75 \mathrm{mg} / \mathrm{L}$ BA ve $0.5 \mathrm{mg} / \mathrm{L} \mathrm{GA}$ içeren sürgün oluşturma ortamından gelen sürgünlerin $400 \mathrm{mg} / \mathrm{L}$ sefotaksim sodyum ve farkl1 NAA konsantrasyonu bulunan ortamlarda kültüre alınması ve oluşan bitkilerin saksıya aktarılması sonucu elde edilen ortalama değerler

\begin{tabular}{cccc}
\hline NAA $(\mathrm{mg} / \mathrm{L})$ & $\begin{array}{c}\text { Canlı kalan eksplant oranı } \\
(\%)\end{array}$ & $\begin{array}{c}\text { Kallus oluşturan bitki } \\
\text { oranı }(\%)\end{array}$ & $\begin{array}{c}\text { Kök oluşturan bitki oranı } \\
(\%)\end{array}$ \\
\hline 0 & 100.00 & $0.00^{\mathrm{c}}$ & 8.33 \\
0.03 & 100.00 & $58.33^{\mathrm{b}}$ & 25.00 \\
0.05 & 100.00 & $75.00^{\mathrm{b}}$ & 25.00 \\
0.07 & 100.00 & $100.00^{\mathrm{a}}$ & 53.33 \\
Tukey HSD (\% 5) & Ö.D & 11.32 & Ö.D \\
\hline
\end{tabular}

Varyans analizi önemli bulunan uygulamaların aynı sütundaki ortalamaları arasındaki farklılıklar, Tukey testiyle $\mathrm{P} \leq 0.05$ 'e göre belirlenmiştir. ÖD: Önemli Değil 


\section{Dikenli Kabağın In Vitro Rejenerasyonu Üzerine Çalışmalar}

\begin{abstract}
Sonuç
Yaprak eksplantlarının yüzeysel dezenfeksiyonu için eksplantların \% 0.5 veya 0.60 sodyum hipoklorit çözeltisinde $15 \mathrm{dk}$ bekletilmesinin uygun olacağı belirlenmiştir. Sefotaksim sodyum uygulamasının yaprak eksplantlarına zarar verdiği gözlemlendiğinden sefotaksim sodyum içermeyen ortamda, in vitro koşullarda büyütülen bitkilerin yaprakları kullanılarak denemenin kurulmasinın daha uygun olduğu belirtilebilir.
\end{abstract}

Sürgün ucu ve tomurcuk eksplantlarının yüzeysel dezenfeksiyonu için denenen farklı konsantrasyon ve süreler arasında, Eksplantların \% 70 etil alkolde 5 sn ve ardından $\% 0.60$ sodyum hipokloritte $15 \mathrm{dk}$ bekletmenin yeterli olacağ 1 belirlenmiştir. Ancak bitkilerde endojenik bakteri infeksiyonu tespit edildiğinden, doku kültürü ortamlarına 400 $\mathrm{mg} / \mathrm{L}$ sefotaksim sodyum eklenerek söz konusu bakteri gelişimi baskı altına alınabilir. Dikenli kabak meyvelerinin sürmesiyle oluşan ve in vitro sonucu elde edilen bitkilerin gerçek yaprak eksplantlariyla kurulan rejenerasyon çalışmalarında, denenen ortamlarda sürgün rejenerasyonu gerçekleşmemiştir. Dikenli kabak yapraklarının hassas olmasından dolayı denemeye alınan bu konsantrasyonlarda değişikliğe gidilerek çalışmaların devam ettirilmesi gerektiği belirtilebilir. Sürgün ucu ve tomurcuk rejenerasyonu çalışmalarında denenen ortamlar arasinda, sefotaksim sodyum uygulamalarıyla birlikte en uygun sürgün oluşturma ortamlarının $0.5 \mathrm{mg} / \mathrm{L}$ BA veya 0.75 $\mathrm{mg} / \mathrm{L}$ BA içeren MS ortamları olduğu sonucuna varılmıştır. Sürgün ucu ve tomurcuk eksplantlarının rejenerasyonu sonucu süren ve kardeşlenen köksüz bitkileri köklendirmek amaciyla kurulan denemelerde, köklenmeyle ilgili gözlemler genel olarak değerlendirildiğinde; köklenme ortamı olarak $0.05 \mathrm{mg} / \mathrm{L}$ NAA ve $400 \mathrm{mg} / \mathrm{L}$ sefotaksim sodyum içeren MS veya sadece $400 \mathrm{mg} / \mathrm{L}$ sefotaksim sodyum eklenen MS ortamlarının kullanılması gerektiği belirlenmiştir. Araştırmada elde edilen bitkilerde yapılan Flow Sitometri analizine göre üretilen bütün rejenerantların diploid olduğu tespit edilmiştir. Ploidi açısından varyasyon meydana gelmemiştir. Bu sonuç, tomurcuk ve sürgün ucu eksplantlarının dikenli kabakta çoğaltma amaçlı kullanılabileceğini ortaya koymaktadır.

\section{Teşekkür}

Çalışmamıza desteğinden dolayı MKÜ BAP birimine (Proje No: 16484), ayrıca Flow Sitometri analizinde yardımcı olan Niğde Ömer Halisdemir Üniversitesi, Tarım Bilimleri ve Teknolojileri Fakültesi, Tarımsal Genetik Mühendisliği Bölümü öğretim üyeleri Prof. Dr. Mehmet Emin ÇALIŞKAN ve Doç. Dr. Ahmet Latif TEK'e teşekkür ederiz.

\section{Kaynaklar}

Abdelnour, A., Engelmann, F. (2002a) Cryopreservation of Chayote (Sechium edule jacq. sw.) zygotic embryos and shoot-tips from in vitro plantlets. CryoLetters 23:281-282, c/o Royal Veterinary College, London NW1 0TU, UK.

Abdelnour, A., Ramirez, C., Engelmann, F. (2002b) Micropropagación de chayote (Sechium edule Jacq. SW.) a partir de brotes vegetativos. Agron. Mesoam. 13(2): 147-151.

Aung, L. H., Ball, A., Kushad, M. (1990) Developmental and nutritional aspects of chayote (Sechium edule, Cucurbitaceae) Econ. Bot. 44 (2):157164.

Cruz-Martínez, V. O., CastellanosHernández, O. A., AcevedoHernández, G. J, Rodríguez- Sahagún, A. (2013) Evaluation of different methods for in vitro plant regeneration of Sechium edule. XV Congreso Nacional de Biotecnología y Bioingeniería. 23-28 Junio, 2013 Cancún, México.

Cruz-Martínez, V., Castellanos-Hernández, O. A., Acevedo-Hernández, G. J, Torres-Morán, M. I., Gutiérrez-Lomelí, M., Ruvalcaba-Ruiz, D., Zurita, F., Rodríguez- Sahagún, A. (2017) Genetic fidelity assessment in plants of Sechium edule regenerated via organogenesis. $\mathrm{S}$. Afr. J. Bot. 112:118-122.

Donato, M. D. and Cequea, H. (1994) A Cytogenetic study of six cultivars of the 
Chayote, Sechium edule Sw. (Cucurbitaceae). J. Hered. 85 (3).

Cadena-Iniguez, J., Arevalo-Galarza, L., Avendano-Arrazate, C. H., SotoHernandez, M., Ruiz-Posadas, L. D., Santiago-Osorio, E., Acosta-Ramos, M., Cisneres-Solano, V. M., AguirreMedina, J. F., Ochoa-Martinez, D. (2007) Production, genetic, postharvest management and pharmacological characteristics of Sechium edule (Jacg.) Sw. Fresh Produce 1 (1):41-53.

Murashige, T. and Skoog, F. (1962) A revised medium for rapid growth and bioassay with tobacco tissue cultures. Physiol. Plan. 15:473-497.

Newstrom, L. E. (1991) Evidence for the origin of Chayote, Sechium edule (Cucurbitaceae). Econ. Bot. 45 (3):410-428.

Ordonez, A., Gomez, J. D., Vattuone, M. A., 1sla, M. I. (2006) Antioxidant activities of Sechium edule (Jacq.) Swartz extracts. Food Chemistry 97:452-458.

Robinson, R.W. and Decker-Walters, D.S., (1997) Cucurbits. CAB International, Wallingford, U.K. pp:266.

Rubatzky, V. E. and Yamaguchi, M. (1997) World vegetables (principles, production and values, second edition). International Thomson Publishing, New York, USA. pp: 842.

Saade, R. L. (1996) Chayote, Sechium edule (Jacq.) Sw. promoting the conservation and use of underutilized and neglected crops. 8. Institute of Plant Genetics and Crop Plant Research, Gatersleben/International Plant Genetics Resources Institute, Rome, Italy.

Sobti, S. N. and Singh, S.D. (1961) A chromosome survey of Indian medicinal plants. Part I. Proc. Indian Acad. Sci. 54:138-144.

Sommaribas, G., Sandoval, J., Muller, L. (1997) Propagacion vegetativa in vitro de Chayote (Sechium edule (Jacq) Sw.) fase de establecimiento. Turrialba, 41:538-544.

Sweetly, S., Vijaya Rani Asha, R., Ramesh Babu, N. G. (2018) Shoot reclamation of chayote from nodes through micropropagation. World. J. Pharm. Pharm. Sci. 7 (10):1104-1112.

Tuna, M., Flow sitometri ve tarımsal araştırmalarda kullanımı. II. Flow Sitometri ve Tarımsal Araştırmalarda Kullanımı Eğitim Programı notları, 1617 Ocak 2014, Tekirdağ.

Wang, X., Li, B., Wang, G. (1997) Regeneration of plants from hypocotyl of Sechium edule Swartz. Cucurbit Genet. Coop. Rep. 20: 65. 